\title{
The National Alcohol Survey of Households in Trinidad and Tobago (NASHTT): willingness to support changes in policy, laws and regulations
}

Rohan G. Maharaj ${ }^{1,2^{*}}$, Terence Babwah ${ }^{1}$, M. Shastri Motilal ${ }^{1}$, Paula Nunes ${ }^{1}$, Rachel Brathwaite ${ }^{1}$, George Legall ${ }^{1}$ and Sandra D. Reid ${ }^{3}$

\begin{abstract}
Background: Over $60 \%$ of households (HHs) in Trinidad and Tobago (T\&T) consume alcohol. These HHs were more likely to report illnesses, relationship problems, and behavioral problems with children. This study set out to determine what proportion of HHs were willing to support changes in specific policies, laws and regulations in a national alcohol campaign.

Methods: A cross-sectional convenience sample of HHs were surveyed from a random sample of enumeration districts (ED) in T\&T. An interviewer-applied, field pre-tested de novo questionnaire had 5 domains and was developed over 1 $1 / 2$ years after an extensive literature review and consultation. Many of the WHO 'best buys' recommendations were included.

Results: One thousand six hundred ninety-five HHs (from 53 ED) responded from a total of $1837 \mathrm{HHs}$ approached (response rate 92\%). In a national campaign the following proportions of $\mathrm{HHs}$ would support: setting the legal age for drinking at 21 years (82.4\%); restricting or banning alcohol advertising on TV and other media (73.1\% and 54 . $4 \%$ respectively); banning all alcohol advertising at sports and cultural events (64.8\%); banning radio stations playing songs with reference to alcohol use (71.3\%); holding sellers of alcohol responsible for the amount of alcohol sold (79. $5 \%)$; advocating that proof of age to be shown by persons buying alcohol (87.4\%); placing more prominent warning labels on products displaying alcohol content (87.2\%); placing more prominent warning labels on products showing harmful effects (88.5\%); increasing taxes on alcohol sales (87.7\%). Less than $50 \%$ of HH supported restrictions in density of outlets and reduction in opening times for alcohol outlets.
\end{abstract}

Conclusions: Many HHs in T\&T are willing to support changes in policies around alcohol, including many of the policies shown by the WHO to be effective in reducing the harmful consumption of alcohol.

Keywords: Alcohol drinking, Trinidad, Tobago, Public opinion, Policy

\footnotetext{
* Correspondence: rohan.maharaj@sta.uwi.edu

${ }^{1}$ The Unit of Public Health and Primary Care, Department of Paraclinical

Sciences, The University of the West Indies, St. Augustine, Trinidad

${ }^{2}$ Alcohol Policy Advisor, The Healthy Caribbean Coalition, Bridgetown,

Barbados

Full list of author information is available at the end of the article
}

(c) The Author(s). 2018 Open Access This article is distributed under the terms of the Creative Commons Attribution 4.0 International License (http://creativecommons.org/licenses/by/4.0/), which permits unrestricted use, distribution, and reproduction in any medium, provided you give appropriate credit to the original author(s) and the source, provide a link to the Creative Commons license, and indicate if changes were made. The Creative Commons Public Domain Dedication waiver (http://creativecommons.org/publicdomain/zero/1.0/) applies to the data made available in this article, unless otherwise stated. 


\section{Background}

Alcohol is associated with adverse medical and social conditions, both acute and chronic [1]. Indeed, alcohol presents an ongoing Caribbean public health problem. The Global Student Health Survey reported that in studies between 2003 and 2010, 45\% of youth aged 1315 years in the English speaking Caribbean (ESC) self-reported alcohol use in the past 30 days [2]. More disturbing was the report that $22 \%$ of this group reported drinking so much alcohol that they staggered, vomited, or developed slurred speech at least once in their life [2]. Among adults 15-64 years old, in Trinidad and Tobago (T\&T), 40.4\% consumed alcohol in the past 30 days, $50.6 \%$ males and $30.9 \%$ females. This increases to $50.2 \%$ among the $25-34$ year age sub-group, for both sexes [3]. The percentage of males who engaged in heavy episodic drinking (HED), ranged between 22\% in Barbados and $33.9 \%$ in Trinidad and Tobago and between 9.7 and $16.8 \%$ for females in these islands respectively [3, 4]. Among the countries in the Americas in 2010, $72.9 \%$ of male youth in T\&T admit to HED, the highest in the region [5].

In $\mathrm{T} \& \mathrm{~T}$, noncommunicable diseases (NCDs) account for $80 \%$ of overall mortality [6]. Alcohol use is recognized as a major contributor to NCDs including hypertension, stroke, cancer, and liver disease and is a major contributor to violence, including domestic violence, and injury among peoples of Latin America and the Caribbean (LAC). In 2002, alcohol was responsible for nearly $10 \%$ of all Disability Adjusted Life Years (DALY) lost in the LAC, compared to the global figure of 4.4\% [6]. Alcohol contributed to $20-50 \%$ of road traffic fatalities in the LAC, and $50.5 \%$ of the alcohol-attributable deaths in the Americas in 2002 were due to injuries [7]. In 2005, adult per capita consumption of alcohol in the Americas was $8.7 \mathrm{~L}$ per year-higher than the world average of $6.1 \mathrm{~L}$ [7].

The role of alcohol as a contributor to disease, notably NCDs has been recognized by Caribbean governments. In 1999, The Caribbean Cooperation in Health Phase II ( $\mathrm{CCH}$ II) identified the strengthening of alcohol prevention and control programmes as a priority issue in the context of the prevention of mental health disorders [8]. And in 2007, the Declaration of Port of Spain acknowledged alcohol as a causal risk factor for NCDs [9].

Despite these statistics and declarations there is ambivalence towards alcohol in the media and the general population. All the countries in the archipelago and on the mainland, have some restrictions on alcohol notably excise duty and taxes, regulations on underage sales, and drunk driving, but only The Bahamas and Jamaica are reported to have any restrictions on advertising and marketing [10]. Alcohol can be sold by many establishments in Trinidad and Tobago, for example, on an 'any day, any time' basis, and many petrol stations also sell alcohol. Many politicians are involved in protecting the local and regional alcohol production and trade against global interests [11]. See Table 1 for a summary of laws and regulations on alcohol in T\&T [12].

There is a strong historical connection to alcohol, notably rum, in the Caribbean. These connections are over 300 years old [13-15]. Many of the globally recognized icons of Caribbean excellence are alcohol based: Angostura (Trinidad), Demerara Rums (Guyana), Appleton (Jamaica), and Mount Gay (Barbados). Tourism remains the major source of revenue for most islands in the region and many fear that placing restrictions on alcohol will harm this trade. However, there is a public health price.

Table 1 Alcohol related policy in Trinidad and Tobago [12]

\begin{tabular}{|c|c|}
\hline $\begin{array}{l}\text { National Policies and Government Support; } \\
\text { National Monitoring Systems }\end{array}$ & Present? \\
\hline $\begin{array}{l}\text { Written national policy (adopted/revised)/ } \\
\text { National Action Plan }\end{array}$ & $\mathrm{No}^{\mathrm{a}}$ \\
\hline $\begin{array}{l}\text { National government support for } \\
\text { community action }\end{array}$ & Yes \\
\hline National monitoring system(s) & Yes \\
\hline \multicolumn{2}{|l|}{$\begin{array}{l}\text { Taxes and National Maximum Blood Alcohol } \\
\text { Concentration (BAC) }\end{array}$} \\
\hline Excise tax on beer/ wine/ spirits & Yes (all three) \\
\hline $\begin{array}{l}\text { National maximum legal blood alcohol } \\
\text { concentration (BAC) when driving a } \\
\text { vehicle (general/young/professional) }\end{array}$ & $0.08 \%$ (for all 3) \\
\hline \multicolumn{2}{|l|}{ Minimum Age interactions } \\
\hline $\begin{array}{l}\text { National legal minimum age for } \\
\text { off-premise sales of alcoholic } \\
\text { beverages (beer, wine, spirits) }\end{array}$ & 18 years \\
\hline $\begin{array}{l}\text { National legal minimum age for } \\
\text { on-premise sales of alcoholic } \\
\text { beverages (beer, wine, spirits) }\end{array}$ & 18 years \\
\hline Minimum drinking age & None \\
\hline \multicolumn{2}{|l|}{$\begin{array}{l}\text { Restrictions for on-/off-premise } \\
\text { sales of alcoholic beverages }\end{array}$} \\
\hline $\begin{array}{l}\text { Time (hours and days) / location } \\
\text { (places and density) }\end{array}$ & $\begin{array}{l}\text { No, } \\
\text { No/ } \\
\text { Yes, } \\
\text { No }\end{array}$ \\
\hline $\begin{array}{l}\text { Specific events / } \\
\text { intoxicated persons / } \\
\text { petrol stations }\end{array}$ & $\begin{array}{l}\text { Yes/ } \\
\text { Yes/ } \\
\text { No }\end{array}$ \\
\hline \multicolumn{2}{|l|}{ Advertising, Marketing and Labeling } \\
\hline $\begin{array}{l}\text { Legally binding regulations on } \\
\text { alcohol advertising / product } \\
\text { placement }\end{array}$ & No \\
\hline $\begin{array}{l}\text { Legally binding regulations on } \\
\text { alcohol sponsorship / sales promotion }\end{array}$ & No \\
\hline $\begin{array}{l}\text { Legally requiring health labels on } \\
\text { alcohol advertisements/containers, }\end{array}$ & No \\
\hline
\end{tabular}

${ }^{\mathrm{a}} \mathrm{A}$ draft policy has been created but it has not been put forward for national discussion, disseminated or accepted by the Cabinet of the government 
Before policies and strategies can be developed and implemented to temper harmful alcohol use, an assessment of the population's desire for change needs to be conducted.

An aim of the NASHTT was to determine the changes to alcohol related laws, regulations, advertisements and other policies that would be acceptable to households in Trinidad and Tobago and what proportion of $\mathrm{HHs}$ would be willing to support these changes? Also we set out to determine whether there were significant differences in support between $\mathrm{HH}$ where alcohol was consumed versus those where it was not; and $\mathrm{HH}$ where there was HED versus those where there was no HED?

\section{Methods \\ Design}

A cross-sectional convenience sample of households $(\mathrm{HH})$ was surveyed from a random selection of enumeration districts in Trinidad and Tobago, the questionnaire was applied by the interviewer in a face-to-face session.

\section{Instrument}

A de novo questionnaire was developed after a literature review and formal consultation with family physicians, a psychiatrist, a sociologist, a statistician and public health specialists. Documents such as the draft Ministry of Health of Trinidad and Tobago's National Policy on Alcohol [16] and Babor's Alcohol: No Ordinary Commodity [1] provided background information for section 4 of the instrument (See below). The survey instrument had five [5] domains with 50 items altogether and was developed over the period January 2012-March 2013. The 5 domains were:

1. The HH's use of alcohol

2. The social, medical and psychological impact of alcohol use on the respondent's immediate $\mathrm{HH}$, family members or relatives, friends or co-workers. The results of the survey findings of these first 2 domains have been published [17].

3. The HH's impression of the impact of the alcohol trade on their immediate residential environment.

4. The HH's willingness to support changes in national alcohol policies in Trinidad and Tobago.

5. HH's demographics

The instrument was pre-tested on over 40 participants and feedback incorporated.

\section{The interviewers}

With assistance from the Central Statistical Office (CSO) a group of experienced enumerators were identified. These were mature individuals who had worked previously in conducting numerous $\mathrm{HH}$ surveys including a recently concluded national census. A training manual and field manual were created and the interviewers underwent a half day training session.

\section{Sample size}

The sample of the NASHTT was based on the Continuous Sample Survey of the Population (CSSP) conducted by the CSO of the Government of Trinidad and Tobago biannually. This CSSP reaches approximately $3200 \mathrm{HHs}$ or $1.5 \%$ of the national HHs.

\section{Selection of $\mathrm{HH}$}

The CSO provided a list of national Enumeration Districts (EDs) and from these a random sample of EDs was taken, Tobago included. There are 2824 EDs in T\&T. EDs represent $\mathrm{HHs}$ of similar economic status and may contain between 250 and 600 HHs. We selected 72 EDs, using a random number generator from Excel. The 72 maps for each ED were purchased from CSO. Using the ED maps, interviewers planned to interview about 40$50 \mathrm{HHs}$ per ED, hence achieve the sample of the CSSP. A sampling interval of 3-6 was used for each ED, depending on the size of the EDs. Larger EDs (HHs greater than 300) used a sampling interval of 6, Medium EDs (HHs between 250 and 300) a sampling interval of 5 and EDs between 200 and $250 \mathrm{HHs}$, a sampling interval of 3-4. Enumerators started the sampling at a fixed point set by the CSO in each ED and applied the sampling interval for that ED.

Because of limited financial resources, return visits to $\mathrm{HH}$ was not possible. As such, if one $\mathrm{HH}$ refused to participate or was ineligible to participate, successive $\mathrm{HH}$ were approached, immediately next to the $\mathrm{HH}$ that refused, until a response was received. After this the sampling interval for that ED was reapplied. In the case that the $\mathrm{HH}$ on the map is found to be a condominium or apartment building, the same interval strategy was used, counting each condominium or apartment as an individual household.

\section{Selection of respondent}

Persons eligible to answer the questionnaire were in the order of preference: 1 . "Household head" or whosoever the person answering the door identified as household head; 2. Any person over the age of 18 years who was knowledgeable of the $\mathrm{HH}$ and willing to participate. Only one [1] questionnaire per household was allowed, but more than one person in the $\mathrm{HH}$ could have contributed answers.

\section{Non-response rate}

Non-consenting $\mathrm{HHs}$ were recorded to determine the non-response rate. 


\section{Consent process}

Once a possible respondent was identified information on the study was shared. The interviewer read out the preamble to the questionnaire which provided extensive information on the purpose of the study and what would be required of participants. Agreeing participants completed and signed the accompanying consent form. Participants were given their signed consent form and signed a separate consent sheet for researchers' records.

\section{Statistical analysis}

This was done using SPSS v 20, IBM, Chicago. Demographic data and independent variables were analysed using simple frequencies. Cross tabulation was done between the dependent variables $\mathrm{(HH}$ where persons consume alcohol OR HH where no alcohol is consumed) AND each of the proposed policies.

Cross tabulation was done between the dependent variables ( $\mathrm{HH}$ by reported Major Ethnicity (Afro-Trinidadian/Indo-Trinidadian/Mixed Ethnicity/Other), Highest achieved Education (Primary (7 years of education) or Lower/Secondary (12-14 years of education)/ Post Secondary (17 years and beyond) and reported Income Level (Low/ Low Middle/ High Middle/ High) of the $\mathrm{HH}$ AND each of the proposed policies. Chi square and associated $p$ values were then obtained. The level of significance was set at alpha $=0.5$.

Cross tabulation was done between the dependent variable 'heavy episodic drinking (HED)' or 'no HED' by $\mathrm{HH}$ and each of the proposed campaigns. Chi square and associated $p$ values were then obtained. The level of significance was set at alpha $=0.5$.

Binary logistic regression was conducted with the change in policy as the dependent variable, and the demographic as the covariate. The following were used as the comparator variable: Afro-Trinidadian for ethnicity, Low income for income and primary/lower for education). ORs, CIs and $p$-values were calculated.

\section{Results}

Fifty-three EDs accounting for $1.8 \%$ of national EDs, were surveyed. Of 1837 households approached, 1695 responded (response rate $92 \%$ ). In $81.5 \%$ of the households (HHs) the head of the $\mathrm{HH}$ was the main respondent. In total the $1695 \mathrm{HH}$ represented 5525 adults (2734 men and 2791 women) and 1553 persons under 18 yrs. $\mathrm{HH}$ reported the predominant ethnicity as African (41.4\%), East Indian (29.4\%) and mixed (28.1\%). At least one person was employed fulltime in $80.4 \%$ of the $\mathrm{HHs}$ and the self reported income were low (31\%), low middle (53\%), upper middle (15\%) and high (1\%) income categories respectively. The most common type of dwelling was privately owned housing (80.8\%) and most dwellings were either brick or concrete structures (76.9\%). The highest level of schooling completed by the head of the $\mathrm{HH}$ was primary $(25.8 \%)$, secondary $(40.5 \%)$ and tertiary (23.1\%) level respectively. With regards to monthly income brackets (TT dollars), HHs reported distribution was \$2000-\$4999 (28.7\%), \$5000-\$7999 (19.7\%), $\$ 8000-\$ 9999$ (15.2\%) and $\$ 10,000-19,999$ (19.5\%).

\section{What would your HH support in a national campaign? Drinking age}

In a national campaign over $80 \%$ of $\mathrm{HH}$ would support setting the legal age for drinking at 21 years and advocating for proof of age to be shown by persons purchasing alcohol. Almost $80 \%$ would support holding the seller responsible for alcohol sales.

\section{Breathalyzer}

Nine out of 10 respondents would support stricter enforcement of the breathalyzer, and an increased public education campaign. See Table 2.

\section{Advertising}

The majority, 50-73\%, of households supported changes in the advertising and delinking advertising with social success, sex, driving and physical performance on TV and other media, and banning songs on the radio that have a reference to alcohol use. See Table 2.

\section{The nature of advertising}

$62.7 \%$ of $\mathrm{HH}$ would support a campaign to delink consumption of alcohol with social success and sex and $69.4 \%$ would support a campaign to delink consumption of alcohol with driving and physical performance. See Table 2

\section{Retail sales}

Regarding retail sales of alcohol more than $75 \%$ of $\mathrm{HH}$ would support a national campaign holding sellers of alcohol responsible for the amount of alcohol sold (to a particular costumer on any one occasion), advocating that proof of age to be shown by persons buying alcohol; placing more prominent warning labels on products displaying alcohol content; placing more prominent warning labels on products showing harmful effects. See Table 2 for further description.

\section{Density of alcohol outlets}

87.1\% of $\mathrm{HH}$ reported having more than one outlet for retail alcohol sales within walking distance of their residence $(1-2 \mathrm{~km})$ and $31.9 \%$ reported having more than three. Between 5 and $15 \%$ of $\mathrm{HH}$ reported being annoyed by the number of bars in their neighborhood (10\%), wishing to see fewer bars in their neighborhood (15\%), being disturbed by noise from the bars (8\%) and being disturbed by patrons of the bars (8\%). In a national 
Table 2 Test of association between HH where alcohol is used and those where alcohol is not used and willingness to support national alcohol campaigns

\begin{tabular}{|c|c|c|c|}
\hline $\begin{array}{l}\text { National Campaign } \\
\text { (Willingness to support) }\end{array}$ & $\begin{array}{l}\mathrm{HH} \text { not using alcohol } \\
N=638(\%)\end{array}$ & $\begin{array}{l}\text { HH using alcohol } \\
N=1055(\%)\end{array}$ & Chi square, $p$ value \\
\hline \multicolumn{4}{|l|}{ Breathalyzer/driving } \\
\hline Stricter enforcement of breathalyser & $582(91.2)$ & $936(88.7)$ & $2.4,0.12$ \\
\hline Increase fines for drunk driving & $567(88.8)$ & $900(85.3)$ & $3.9,0.048$ \\
\hline \multicolumn{4}{|l|}{ Taxation } \\
\hline Increase taxes on alcohol sales & $580(90.9)$ & $890(84.4)$ & $14.3,<0.001$ \\
\hline \multicolumn{4}{|l|}{ Public education } \\
\hline Increase public education campaign & $582(91.2)$ & $950(90.0)$ & $0.52,0.47$ \\
\hline \multicolumn{4}{|l|}{ Advertising and media } \\
\hline Restrict alcohol advertising on TV etc & $470(73.7)$ & $765(72.5)$ & $0.2,0.64$ \\
\hline Ban all alcohol advertising on TV etc & $389(61.0)$ & $504(47.8)$ & $27.3,<0.001$ \\
\hline Ban all alcohol advertising at sports, cultural events & $428(67.1)$ & $659(62.5)$ & $3.5,0.06$ \\
\hline Ban radio stations playing songs with reference to alcohol use & $485(76.0)$ & $702(66.5)$ & $16.6,<0.001$ \\
\hline Delink consumption of alcohol with social success and sex & $417(65.4)$ & $632(59.9)$ & $4.8,0.03$ \\
\hline Delink consumption of alcohol with driving and physical performance & $443(69.4)$ & $731(69.3)$ & $0.0,0.99$ \\
\hline \multicolumn{4}{|l|}{ Adolescent issues } \\
\hline Set legal age limit for drinking at 21 yrs & $514(80.6)$ & $888(84.2)$ & $3.3,0.07$ \\
\hline Hold sellers of alcohol responsible for the amount of alcohol sold & $527(82.6)$ & $806(76.4)$ & $8.8,0.003$ \\
\hline Advocate proof of age to be shown by persons buying alcohol & $557(87.3)$ & $922(87.4)$ & $0.00,1$ \\
\hline \multicolumn{4}{|l|}{ Labelling and retail sales } \\
\hline More prominent warning labels on products displaying alcohol content & $566(88.7)$ & $904(85.7)$ & $2.9,0.09$ \\
\hline More prominent warning labels on products showing harmful effects & $575(90.1)$ & $917(86.9)$ & $3.6,0.06$ \\
\hline \multicolumn{4}{|l|}{ Reduce availability } \\
\hline Reduce opening hours of bars and rum shops & $241(37.7)$ & $396(37.5)$ & $0.61,0.74$ \\
\hline Would like to see fewer bars and rum shops operating in your community & $177(19.8)$ & $127(12.1)$ & $18.9,<0.001$ \\
\hline
\end{tabular}

campaign $37.6 \%$ of $\mathrm{HH}$ would support reducing the opening hours of bars and rum shops.

\section{Taxation}

In a national campaign over $80 \%$ of $\mathrm{HH}$ would support increasing taxes on alcohol sales.

\section{Comparison of willingness to support national campaigns between $\mathrm{HH}$ where alcohol is used and those where alcohol is not used}

Table 2 provides a comparison of the willingness of $\mathrm{HH}$ to support a national campaign based on whether alcohol is used in that $\mathrm{HH}$ or not. Generally there was wide support for the proposed policies regardless of whether alcohol was consumed in that $\mathrm{HH}$ or not. There was less support by $\mathrm{HHs}$ in which alcohol was consumed for: banning all alcohol advertising on TV and media, banning radio stations from playing songs with reference to alcohol, holding sellers of alcohol responsible for the amount sold, increasing taxes and increasing fines for drunk driving $(p<0.05)$.

We conducted a regression analysis on the statistically significant elements and found that only one campaign remained significant depending on whether the $\mathrm{HH}$ used alcohol or not. The odds of favouring a ban on all alcohol advertising on TV is 1.53 times higher among households in which no alcohol is consumed than among households in which alcohol is consumed.

\section{What would your $\mathrm{HH}$ support in a national alcohol campaign by characteristics of $\mathrm{HH}$ ?}

Table 3 provides the results of the analysis of the variety of policies supported by the $\mathrm{HH}$, depending on the characteristics of the $\mathrm{HH}$.

\section{Ethnicity of $\mathrm{HH}$}

Compared to African $\mathrm{HHs}$, East Indian $\mathrm{HHs}$ were more likely to support raising the legal age to 21 yrs., restricting or banning all advertisements, banning radio songs which 
Table 3 Willingness to support national campaigns by demographics

\begin{tabular}{|c|c|c|c|}
\hline \multirow{2}{*}{$\begin{array}{l}\text { Which of the following changes do you } \\
\text { believe members of this household } \\
\text { would support in a national campaign? }\end{array}$} & \multicolumn{3}{|c|}{ Unadjusted Odds Ratio (95\% confidence interval) } \\
\hline & $\begin{array}{l}\text { Ethnicity }^{\mathrm{a}} \\
\text { East Indian vs. African; } \\
\text { Mixed vs. African }\end{array}$ & $\begin{array}{l}\text { Education level } \text { brc }^{\mathrm{b}} \\
\text { Secondary vs. Primary/lower; } \\
\text { Post- secondary vs. Primary/lower }\end{array}$ & $\begin{array}{l}\text { Income Level }^{d} \\
\text { Low middle vs. Low; } \\
\text { Upper middle vs. Low; } \\
\text { High vs. Low } \\
\end{array}$ \\
\hline Set the legal age for drinking at 21 years & $\begin{array}{l}2.364(1.675-3.336) \\
1.282(0.949-1.732)\end{array}$ & $\begin{array}{l}1.455(\mathbf{1 . 0 5 8 - 2 . 0 0 2 )} \\
0.855(0.633-1.155)\end{array}$ & $\begin{array}{l}1.498(0.885-2.534) \\
\mathbf{2 . 1 0 9}(\mathbf{1 . 2 6 2 - 3 . 5 2 5 )} \\
1.704(0.952-3.050)\end{array}$ \\
\hline $\begin{array}{l}\text { Restricting alcohol advertisements } \\
\text { on TV/radio/newspapers/cinema }\end{array}$ & $\begin{array}{l}2.305(1.738-3.057) \\
1.206(0.934-1.557)\end{array}$ & $\begin{array}{l}1.391(1.077-1.797) \\
1.476(1.122-1.942)\end{array}$ & $\begin{array}{l}1.094(0.679-1.764) \\
1.751(1.097-2.793) \\
2.291(1.330-3.945)\end{array}$ \\
\hline $\begin{array}{l}\text { Ban of all alcohol advertisements } \\
\text { on TV/radio/newspapers/cinema }\end{array}$ & $\begin{array}{l}2.537(1.992-3.230) \\
0.959(0.759-1.212)\end{array}$ & $\begin{array}{l}1.381(1.100-1.732) \\
1.323(1.042-1.681)\end{array}$ & $\begin{array}{l}0.969(0.613-1.531) \\
1.146(0.735-1.785) \\
1.404(0.856-2.304)\end{array}$ \\
\hline $\begin{array}{l}\text { Ban of all alcohol advertisements } \\
\text { at cultural or sporting events }\end{array}$ & $\begin{array}{l}1.466(1.141-1.883) \\
0.744(0.586-0.945)\end{array}$ & $\begin{array}{l}1.049(0.829-1.328) \\
1.006(0.785-1.289)\end{array}$ & $\begin{array}{l}2.236(1.406-3.555) \\
2.562(1.634-4.017) \\
2.935(1.767-4.875)\end{array}$ \\
\hline $\begin{array}{l}\text { Delinking the consumption of } \\
\text { alcohol with social or sexual success }\end{array}$ & $\begin{array}{l}1.201(0.942-1.530) \\
\mathbf{0 . 7 4 2}(\mathbf{0 . 5 8 5 - 0 . 9 4 2 )}\end{array}$ & $\begin{array}{l}1.021(0.810-1.286) \\
1.246(0.972-1.598)\end{array}$ & $\begin{array}{l}1.879(1.184-2.981) \\
2.097(1.341-3.281) \\
3.032(1.823-5.042)\end{array}$ \\
\hline $\begin{array}{l}\text { Delinking the consumption of alcohol } \\
\text { with driving or physical performance }\end{array}$ & $\begin{array}{l}0.941(0.728-1.216) \\
\mathbf{0 . 6 4 9}(\mathbf{0 . 5 0 5 - 0 . 8 3 3 )}\end{array}$ & $\begin{array}{l}0.834(0.653-1.065) \\
0.791(0.612-1.022)\end{array}$ & $\begin{array}{l}2.633(1.654-4.190) \\
2.912(1.858-4.564) \\
3.421(2.046-5.719)\end{array}$ \\
\hline $\begin{array}{l}\text { Ban of radio stations playing songs } \\
\text { which reference alcohol use }\end{array}$ & $\begin{array}{l}2.147(1.635-2.819) \\
1.008(0.788-1.290)\end{array}$ & $\begin{array}{l}0.959(0.750-1.225) \\
1.057(0.813-1.373)\end{array}$ & $\begin{array}{l}1.882(1.182-2.997) \\
2.074(1.323-3.253) \\
2.209(1.324-3.683)\end{array}$ \\
\hline $\begin{array}{l}\text { Stricter and more intensive } \\
\text { enforcement of breathalyzer }\end{array}$ & $\begin{array}{l}1.520(1.022-2.261) \\
1.209(0.827-1.766)\end{array}$ & $\begin{array}{l}0.706(0.494-1.010) \\
0.953(0.636-1.429)\end{array}$ & $\begin{array}{l}2.248(1.258-4.017) \\
2.821(1.611-4.940) \\
2.651(1.361-5.163)\end{array}$ \\
\hline $\begin{array}{l}\text { Holding sellers of alcohol responsible } \\
\text { for the amount of alcohol they sell to patrons. }\end{array}$ & $\begin{array}{l}1.543(1.151-2.070) \\
1.100(0.833-1.455)\end{array}$ & $\begin{array}{l}0.819(0.625-1.073) \\
1.052(0.781-1.418)\end{array}$ & $\begin{array}{l}2.494(1.548-4.020) \\
3.076(1.939-4.878) \\
2.926(1.715-4.992)\end{array}$ \\
\hline $\begin{array}{l}\text { Advocating for proof of age to be shown } \\
\text { before alcohol is sold to a buyer }\end{array}$ & $\begin{array}{l}1.524(1.046-2.221) \\
0.875(0.626-1.224)\end{array}$ & $\begin{array}{l}\mathbf{0 . 5 4 6}(\mathbf{0 . 3 9 4 - 0 . 7 5 7 )} \\
0.892(0.610-1.304)\end{array}$ & $\begin{array}{l}2.952(1.738-5.014) \\
3.343(2.015-5.545) \\
3.692(1.988-6.858)\end{array}$ \\
\hline $\begin{array}{l}\text { More prominent warning labels on products } \\
\text { displaying the alcohol concentration }\end{array}$ & $\begin{array}{l}1.370(0.951-1.974) \\
0.902(0.644-1.261)\end{array}$ & $\begin{array}{l}\mathbf{0 . 5 4 6}(\mathbf{0 . 3 9 5 - 0 . 7 5 7 )} \\
0.790(0.547-1.140)\end{array}$ & $\begin{array}{l}3.171(1.860-5.405) \\
3.305(1.993-5.479) \\
2.431(1.360-4.347)\end{array}$ \\
\hline $\begin{array}{l}\text { More prominent warning labels on products } \\
\text { displaying the harmful effects of alcohol }\end{array}$ & $\begin{array}{l}1.463(0.994-2.153) \\
0.888(0.627-1.257)\end{array}$ & $\begin{array}{l}0.567(0.401-0.802) \\
0.645(0.444-0.938)\end{array}$ & $\begin{array}{l}3.335(1.921-5.791) \\
3.093(1.844-5.188) \\
2.790(1.515-5.138)\end{array}$ \\
\hline Increased taxation on alcohol & $\begin{array}{l}1.544(\mathbf{1 . 0 6 8 - 2 . 2 3 4 )} \\
0.931(0.668-1.298)\end{array}$ & $\begin{array}{l}\mathbf{0 . 7 1 4}(\mathbf{0 . 5 1 7 - 0 . 9 8 7 )} \\
1.004(0.695-1.450)\end{array}$ & $\begin{array}{l}2.280(1.328-3.917) \\
2.692(1.600-4.529) \\
2.977(1.589-5.576)\end{array}$ \\
\hline $\begin{array}{l}\text { Increase the public education campaigns } \\
\text { on responsible alcohol use in all settings } \\
\text { including in schools }\end{array}$ & $\begin{array}{l}1.227(0.799-1.885) \\
0.701(0.479-1.027)\end{array}$ & $\begin{array}{l}\mathbf{0 . 5 5 0}(\mathbf{0 . 3 7 7 - 0 . 8 0 4 )} \\
0.692(0.457-1.050)\end{array}$ & $\begin{array}{l}2.799(1.547-5.064) \\
2.985(1.701-5.239) \\
2.930(1.487-5.775)\end{array}$ \\
\hline Increased fines for drunk driving & $\begin{array}{l}1.390(0.979-1.971) \\
1.170(0.832-1.645)\end{array}$ & $\begin{array}{l}\mathbf{0 . 6 4 3}(\mathbf{0 . 4 6 5 - 0 . 8 8 9 )} \\
0.830(0.580-1.188)\end{array}$ & $\begin{array}{l}2.490(1.456-4.260) \\
2.435(1.462-4.055) \\
5.032(2.544-9.955)\end{array}$ \\
\hline
\end{tabular}

Odds ratios in bold show significant associations. Confidence intervals are either greater than or less than 1

${ }^{a}$ Comparisons in Ethnicity for East Indian vs. African and Mixed vs. African

${ }^{b}$ Education levels- Primary- 7 years of education; Secondary- 12-14 years of education; Post-secondary- 17 years and beyond

${ }^{c}$ Comparisons in Educations level for Seconday vs.Primary/lower and Post- secondary vs. Primary/lower

${ }^{d}$ Comparisons in Income level for Low middle vs. Low; Upper middle vs. Low and High vs. Low

reference alcohol use, stricter breathalyzer enforcement, holding alcohols sellers responsible for the amount of alcohol they sell, advocating for proof of age before alcohol is sold and increased taxation.
Highest education level achieved by head of $\mathrm{HH}$

$\mathrm{HH}$ where the highest level of education achieved by the head of the $\mathrm{HH}$ was to the secondary level $\mathrm{HHs}$ were more likely to support raising the legal age to 21 yrs. 
and restricting or banning all advertisements in media. However compared to Primary/Low education, Secondary level HHs were less likely to support advocating proof of age, more prominent warnings on products, increases taxation, increasing education campaigns and increasing fines.

\section{Self-reported income level of $\mathrm{HH}$}

Generally higher income categories when compared to low income categories were associated with support for all the changes except regarding the ban on all advertisements.

\section{Heavy episodic drinking (HED) within $\mathrm{HH}$ and the support of policy}

Table 4 illustrates that in both HH where HED occurred and $\mathrm{HH}$ where no HED occurred there was no difference in support for most of the proposed policies and regulation changes, Significant differences occurred however, with less support among $\mathrm{HH}$ with HED for the following policy changes: stricter and more intensive enforcement of breathalyzer, more prominent warning labels on products displaying the alcohol concentration and reduced opening hours.

It was also noted there was less acceptance of the following statements by $\mathrm{HH}$ where HED occurred: that the
$\mathrm{HH}$ was annoyed by the number of bars in their community, that $\mathrm{HH}$ would like to see fewer bars operating in their community, that $\mathrm{HH}$ were disturbed by the noise coming from bars, or that $\mathrm{HH}$ were disturbed by the patrons coming from the bars.

\section{Discussion}

This survey of a large cross-section of the population provides information to policy makers, civil society and public health institutions for addressing change in alcohol policies, laws and regulations in Trinidad and Tobago.

\section{How does these results compare with public opinion on alcohol internationally?}

Recent international reviews suggest that public support is higher for the less effective interventions [18], for $e x$ ample support is lower for policies which seek to restrict the physical and economic availability of alcohol to the wider public..... and higher for policies directed towards informing, educating and treating targeted individuals' [19]. In Australia several studies between 1998 and 2007, reported that $28-40 \%$ of respondents supported reducing trading hours or reducing outlet density where alcohol is served and more than $80 \%$ support stricter enforcement of laws and 69\% supported increased health

Table 4 Test of association between HH where heavy episodic drinking (HED) occurs versus HH where no HED occurs and willingness to support national alcohol campaigns

\begin{tabular}{|c|c|c|c|}
\hline $\begin{array}{l}\text { National Campaign } \\
\text { (Willingness to support) }\end{array}$ & $\begin{array}{l}\text { No Heavy Episodic } \\
\text { Drinking in } \mathrm{HH}(\%)\end{array}$ & $\begin{array}{l}\text { Heavy Episodic Drinking } \\
\text { in } \mathrm{HH}(\%)\end{array}$ & $P$ value \\
\hline Set the legal age for drinking at 21 years & $997(84.9)$ & $514(72.2)$ & 0.006 \\
\hline Restricting alcohol advertisements on TV/radio/newspapers/cinema & $869(73.6)$ & $368(71.6)$ & 0.215 \\
\hline Ban of all alcohol advertisements on TV/radio/newspapers/cinema & 627 (53.1.) & $267(51.9)$ & 0.351 \\
\hline Ban of all alcohol advertisements at cultural or sporting events & $753(63.8)$ & $335(65.2)$ & 0.308 \\
\hline Delinking the consumption of alcohol with social or sexual success & $724(61.3)$ & $326(63.4)$ & 0.220 \\
\hline Delinking the consumption of alcohol with driving or physical performance & $814(68.9)$ & $361(70.2)$ & 0.316 \\
\hline Ban of radio stations playing songs which reference alcohol use & $825(69.9)$ & $364(70.8)$ & 0.368 \\
\hline Stricter and more intensive enforcement of breathalyzer & $1047(88.7)$ & $472(91.8)$ & 0.028 \\
\hline Holding sellers of alcohol responsible for the amount of alcohol they sell to patrons. & $931(78.8)$ & $403(78.4)$ & 0.445 \\
\hline Advocating for proof of age to be shown before alcohol is sold to a buyer & $1029(87.1)$ & $452(87.9)$ & 0.354 \\
\hline More prominent warning labels on products displaying the alcohol concentration & $1008(85.4)$ & $463(90.1)$ & 0.005 \\
\hline More prominent warning labels on products displaying the harmful effects of alcohol & $1032(87.4)$ & $462(89.9)$ & 0.082 \\
\hline Increased taxation on alcohol & $1024(86.7)$ & $448(87.2)$ & 0.433 \\
\hline $\begin{array}{l}\text { Increase the public education campaigns on responsible alcohol use in all settings } \\
\text { including in schools }\end{array}$ & $1070(90.7)$ & $463(90.1)$ & 0.380 \\
\hline Increased fines for drunk driving & $1017(86.3)$ & $449(87.4)$ & 0.314 \\
\hline Reduced opening hours & $485(41.1)$ & $153(29.8)$ & 0.001 \\
\hline Annoyed by the number of bars in your community & $145(12.3)$ & $37(7.2)$ & 0.001 \\
\hline $\mathrm{HH}$ would like to see fewer bars operating in your community & $189(16.0)$ & $65(12.7)$ & 0.009 \\
\hline $\mathrm{HH}$ disturbed by the noise coming from bars & $94(8.0)$ & $21(4.1)$ & 0.011 \\
\hline $\mathrm{HH}$ disturbed by the patrons coming from the bars & $96(8.1)$ & $23(4.5)$ & 0.004 \\
\hline
\end{tabular}


warnings on packaging [19]. Similar elements were found in South Africa [20].

Interestingly some elements of this pattern was found in this current study. This current study found that only $38 \%$ would support reducing trading hours or reducing outlet density. Similarly, in our study, over $90 \%$ would support stricter enforcement of the breathalyzer laws and more extensive labeling highlighting harmful effects. A similar finding for advertising is noted below. Where this study differed is in the support for taxation, whilst $80 \%$ of Trinidadian and Tobagonian respondents supported this, in Australia only $38-42 \%$ did so [19]. A similar low level of support for increased prices (3458\%) was found in South Africa [20].

\section{Why is support for these regulations so strong?}

It is not easy to explain the findings in T\&T compared to the rest of the world as this is the first study to examine the population's willingness to support new policies and regulations on alcohol. Over the years this community has seen an increase in violent crimes, many linked to drug and alcohol use. Also many $\mathrm{HH}$ are affected by intimate partner violence and the effects of alcohol abuse [17]. This idea of second-hand drinking has support in the literature, in this case persons who experienced family or personal aggressive harms or who were concerned about a relative's drinking were more supportive of restrictive alcohol policies [21]. These factors could be affecting the results we obtained. Most persons receive information about alcohol through school, employment, religious forums, media, including online, and peer interaction. Future qualitative type studies might be the mechanism to explore these factors.

\section{Outlet density and availability of alcohol}

In our study, there was poor support for restrictions to be placed on the availability and accessibility to alcohol that would decrease the number of bars and rum shops in the neighbourhood or reduce the duration of their opening hours. The lack of support in this area did not significantly differ between $\mathrm{HH}$ that drank alcohol and those that did not. Internationally however, there is clear evidence that 'substantial changes in the number of alcohol outlets results in significant changes to alcohol consumption and related harms' [1]. Further research needs to be done to better understand the reasons for these local findings.

\section{Advertising}

The lack of policies on advertising and marketing in the $\mathrm{T} \& \mathrm{~T}$ is an obvious gap. There are opportunities for interventions and this report suggested that there was public support. This survey found that many supported cautionary labels to be placed on alcoholic drinks and more than 50\% supported delinking alcohol advertising with success, sex, driving and performance. More than half of all $\mathrm{HH}$ will support a policy banning alcohol advertisements at sporting events or restricting of advertisements in the media. As seen in this study significantly more non-alcohol consuming HHs (61\%) was willing to support a ban on all advertising on TV compared to alcohol consuming HHs (48\%). And half will support banning of all alcohol advertisements in the media. This is an important finding since 'Longitudinal studies consistently suggest that exposure to media and commercial communications on alcohol is associated with the likelihood that adolescents will start to drink alcohol, and with increased drinking amongst baseline drinkers' [22]. There is currently a call for banning alcohol advertisements by the Global Alcohol Policy Alliance [23]. International public opinion polls suggest that roughly similar proportions of other populations support such marketing restrictions [20]. In Australia between 40 and 70\% supported advertising being reduced or banned [19]. In the US, one study reports that $60 \%$ support alcohol advertising and promotion restrictions [24]. Similarly only half of this population, support banning advertising of alcohol.

\section{Adolescents}

The results show that there was good support for more rigorous control of young people drinking. When asked about the implementation of access controls concerning young people (age $<21$ years) support was greater, with more than $3 / 4$ of respondents supporting setting the legal age where alcohol consumption is allowed to 21 years. It may be that young people are viewed as having diminished responsibility and therefore restrictions to access alcohol for this age group is warranted. The international literature supports the view that 'minimum legal purchase age is effective in reducing road fatalities and other harms with minimal enforcement, but enforcement substantially increases effectiveness and the cost' [1]. Recent reports suggests that in South Africa [19] and South Korea [25] there is similar support for increasing the alcohol purchasing age to 20-21 years. Focusing attention on regulations pertaining to adolescent purchasing or possession of alcohol may be an effective use of resources. Increasing the age of alcohol purchasing to 21 in the USA has been accredited with saving the lives of 21,000 persons between 1975 and 2002 [26].

\section{Taxation}

The majority of $\mathrm{HH}$ will support increased taxation on alcohol. This is a promising intervention for many governments, increasing revenue while reducing consumption and harm. It also has the potential to reduce consumption among young people who may have less disposable income."Studies have consistently demonstrated that alcohol prices have an 
effect on levels of consumption and related harms, including mortality rates, crime and traffic accidents." [1].

\section{Study strengths}

The survey had a large sample size and a high response rate. Although this high response rate is in part due to the experience of the interviewers and the relatively short survey instrument, participants also showed keen interest in the area of study "alcohol". Many HHs congratulated the interviewers for investigating alcohol and several persons volunteered to participate in a follow-up study of their personal and family experience of alcohol. With the exception of a ban on all TV advertising, the majority of $\mathrm{HHs}$ in this survey were willing to support changes in policy, independent of alcohol consumption status. This suggests that the population is receptive to the dissemination of information pertaining to alcohol and to the implementation of regulations, laws and policies that have been demonstrated in other countries to be effecting change in alcohol use or misuse. Multiple internet searches using the terms: alcohol, public, opinion and the names of various Caribbean nations gave no relevant papers, so this paper may represent the first such attempt to capture a Caribbean population's opinion on this issue.

\section{Limitations}

It is important to state that while our validation process of the instrument ensured content, face and cultural validity, this scale has not been used or tested before.

Several areas of interest were not studied because of space limitations in questionnaire and lack of information when developing the instrument, these include driving restrictions for drunk drivers, Selling alcohol at gas stations, Alcohol marketing on the internet and social media. Additionally our sample size limited by funding and the full number of EDs could not be surveyed. Although the response rate was high overall, one of the selected enumeration districts was in a very high income neighbourhood, there was limited access to the $\mathrm{HH}$, many with high walls and security. Only a few responses was obtained. Another limitation was not asking whether at least one family member or close relative was involved in a serious or fatal accident, or other negative experience, in which drinking was involved. Such an experience might have influenced their choice of restrictions.

Care should be taken in the interpretation of the items in the chi-square analysis where $p<0.05$, as closer study of the OR show many approaching or just under an OR of 1 or no effect. Only one item, 'banning TV advertisements' was significantly supported by $\mathrm{HH}$ not using alcohol.

\section{Conclusions}

Apart from restrictions in density of outlets and reduction in opening times for alcohol outlets the majority of HHs in $\mathrm{T} \& \mathrm{~T}$ are willing to support changes in policies around alcohol, including many of the policies shown by the WHO to be effective in reducing the harmful consumption of alcohol. The long established alcohol industry has considerable support among governments and other sectors within the region and the change suggested in this paper will be difficult. This will require all stakeholders to have an input, including Civil Society Organizations(CSO). There are roles for a CSO such as the Healthy Caribbean Coalition and the Caribbean Public Health Agency (CARPHA) in promoting this agenda.

\section{Abbreviations \\ CCH II: Caribbean Cooperation in Health II; CSO: Central Statistical Office; CSSP: Continuous Sample Survey of the Population; DALY: Disability Adjusted Life Years; ED: Enumeration District; ESC: English-speaking Caribbean; HED: Heavy Episodic Drinking; HH: Household; LAC: Latin America and The Caribbean; NASHTT: National Alcohol Survey of Households in Trinidad and Tobago; NCD: Non Communicable Disease; SPSS: Statistical Package for Social Sciences; T\&T: Trinidad and Tobago; WHO: World Health Organization}

\section{Acknowledgements}

The authors would like to thank the Central Statistical Office (CSO) who assisted in designing the sampling method and the enumerators from the CSO who conducted the survey. Thanks also to the participants who gave so freely of their time.

\section{Funding}

Funding for this study was received from the Campus Research and Publications Grant of The University of the West Indies, St. Augustine: CRP.3.MAR12.23.

\section{Availability of data and materials}

The data set is available on reasonable request from the first author, RGM. The survey instrument is available online [15].

\section{Authors' contributions}

The paper was conceived by the first author, RGM. RGM, PN, RB, SM, SD, and GL contributed to the development of the survey instrument. GL, RGM, TB and SM contributed to the statistical analysis. All authors contributed to and approve the final submitted version, and give consent for the paper to be published.

\section{Ethics approval and consent to participate}

The project was approved by the Ethics Committee of the Faculty of Medica Sciences, The University of the West Indies, St. Augustine, Trinidad. All study respondents signed a written informed consent after the study details were explained by the interviewer.

\section{Consent for publication}

Not applicable.

\section{Competing interests}

The authors declare that they have no competing interests.

\section{Publisher's Note}

Springer Nature remains neutral with regard to jurisdictional claims in published maps and institutional affiliations.

\section{Author details}

${ }^{1}$ The Unit of Public Health and Primary Care, Department of Paraclinical Sciences, The University of the West Indies, St. Augustine, Trinidad. ${ }^{2}$ Alcohol Policy Advisor, The Healthy Caribbean Coalition, Bridgetown, Barbados. ${ }^{3}$ The Unit of Psychiatry, Department of Medicine, The University of the West Indies, St. Augustine, Trinidad. 
Received: 21 December 2017 Accepted: 11 October 2018

Published online: 25 October 2018

\section{References}

1. Babor T, Caetano R, Casswell S, Edwards G, Giesbrecht N, Graham K, et al. Alcohol: no ordinary commodity-research and public policy. 2nd ed. Oxford: Blackwell Publishing Ltd; 2010.

2. Global School Health Survey. Available from: http://www.who.int/chp/gshs/ trinidadandtobago/en/ Accessed 16 Oct 2014.

3. Ministry of Health, Government of the Republic of Trinidad and Tobago. Trinidad and Tobago Chronic Non-Communicable Disease, Risk Factor Survey [Pan American STEPS] Final Report, 2012. Available from: http://www. health.gov.tt/downloads/DownloadDetails.aspx?id=314

4. Ministry of Health, Barbados. Pan American STEPS. Available from: http://www.who.int/chp/steps/Barbados_2007_STEPS_FactSheet.pdf. Accessed 15 Dec 2017

5. PAHO. Regional status report on alcohol and health in the Americas. Washington, DC 2015. Available from: https://www.paho.org/hq/ dmdocuments/2015/Alcohol-Report-Health-Americas-2015.pdf. Accessed 03 Aug 2018.

6. WHO. Country Profiles. Trinidad and Tobago. Available from: http://www. who.int/nmh/countries/tto en.pdf Accessed 13 Aug 2017.

7. Monteiro MG. Alcohol and public health in the Americas: a case for action. Washington, D.C: PAHO, 2007. Available from: http://www.who.int/substance_ abuse/publications/alcohol_public_health_americas.pdf Accessed 15 Dec 2017.

8. Caribbean Community (CARICOM). Caribbean Cooperation in Health II. Available from https://www.paho.org/ecc/index.php?option=com_ docman\&view=document\&layout=default\&alias=2-caribbean-cooperationin-health-phase-ii-may-1999\&category_slug=publications\&ltemid=154. Accessed 16 Oct 2014

9. Caribbean Community (CARICOM). Declaration of Port of Spain. Available from: https:/caricom.org/media-center/communications/statements-from-caricommeetings/declaration-of-port-of-spain-uniting-to-stop-the-epidemic-of-chronicncds. Accessed 16 Oct 2014.

10. WHO. Country Profiles. Available from: www.who.int/substance abuse/ publications/global_alcohol_report/msbgsruprofiles.pdf. Accessed 16 Oct 2014.

11. The Daily Observer. Regional Governments back rum marketing campaign Available from: https://antiguaobserver.com/regional-governments-backrum-marketing-campaign/ Accessed 15 Dec 2017.

12. Global status report on alcohol and health - 2018 ed. Available from : http://www.who.int/substance_abuse/publications/global_alcohol_report/ en/ Accessed 27 Sept 2018.

13. Curtis W, And a bottle of rum. A history of the word in ten cocktails. New York: Tree Rivers Press; 2006.

14. Williams I. Rum: a social and sociable history. New York: Nation Books; 2006.

15. Smith FH. Caribbean rum: a social and economic history. Gainesville: Florida. University Press of Florida; 2005.

16. Paul A. Government looking at alcohol policy. Available from: https:/www. guardian.co.tt/news/govt-looking-alcohol-policy-6.2.386710.a2aaeb5767 Accessed 16 Oct 2014.

17. Maharaj RG, Motilal MS, Babwah T, Nunes P, Brathwaite R, Legall G, Reid SD, Canavan M, Bradley E. National alcohol survey of households in Trinidad and Tobago (NASHTT): Use of alcohol by households. BMC Public Health. 2017;17:347. https://doi.org/10.1186/s12889-017-4266-z.

18. Nelson TF, Xuan Z, Blanchette JG, Heeren TC, Naimi TS. Patterns of change in implementation of state alcohol control policies in the United States, 1999-2011. Addiction. 2015;110(1):59-68. https://doi.org/10.1111/add.12706.

19. Tobin C, Moodie AR, Livingstone C. A review of public opinion towards alcohol controls in Australia. BMC Public Health. 2011;11:58. https://doi.org/ 10.1186/1471-2458-11-58.

20. Parry CDH, Trangenstein P, Lombard C, Jernigan DH, Morojele NK. Support for alcohol policies from drinkers in the City of Tshwane, South Africa: data from the international alcohol control study. Drug Alcohol Rev. 2017; https://www.ncbi.nlm.nih.gov/pubmed/28493419.

21. Greenfield T, Karriker-Jaffe K, Giesbrecht N, Kerr W, Ye Y, Bond J. Secondhand drinking may increase support for alcohol policies: new results from 2010 National Alcohol Survey. Drug \& Alcohol Review. 2014;33:259-67.

22. Anderson P, de Bruijn A, Angus K, Gordon R, Hastings G. Impact of Alcohol Advertising and Media Exposure on Adolescent Alcohol Use: A Systematic Review of Longitudinal Studies. Alcohol and Alcoholism. 2009:44(3):229-43. https://doi.org/10.1093/alcalc/agn115.
23. Global Alliance Policy Alliance. Global Alcohol Policy Conference 2015. Momentum for change: research and advocacy reducing alcohol harm. Declaration. Available from: http://www.alcohol-focus-scotland.org.uk/ media/173236/gapc-2015-declaration.pdf. Accessed 15 Dec 2017.

24. Wagenaar AC, Harwood EM, Toomey TL, Denk CE, Zander KM. Public opinion on alcohol policies in the United States: results from a National Survey. J Public Health Policy 21(3):303-327 2000. Available from: https:// www.ncbi.nlm.nih.gov/pubmed/11021045. Accessed 15 Dec 2017.

25. Seo S, Chun S, Newell M, Yun M. Korean public opinion on alcohol control policy: a cross-sectional international alcohol control study. Health Policy. 2015;119(1):3343. https://doi.org/10.1016/j.healthpol.2014.10.016 Epub 2014 Nov 20.

26. Kindelberger J. National Highway Traffic Safety Administration. Traffic Safety Facts. Research Notes 2015. Available from: https://crashstats.nhtsa.dot.gov/ Api/Public/NiewPublication/809860. Accessed 14 Aug 2017
Ready to submit your research? Choose BMC and benefit from:

- fast, convenient online submission

- thorough peer review by experienced researchers in your field

- rapid publication on acceptance

- support for research data, including large and complex data types

- gold Open Access which fosters wider collaboration and increased citations

- maximum visibility for your research: over $100 \mathrm{M}$ website views per year

At BMC, research is always in progress.

Learn more biomedcentral.com/submissions 